\title{
A QueSTÃo SOCIAL No RIO GRANDE do SUL: POSITIVISMO, BORGISMO E A INCORPORAÇÃO DO PROLETARIADO À SOCIEDADE MODERNA
}

\author{
César Augusto Bubolz Queirós*
}

\begin{abstract}
RESUMO: Este artigo tem como objetivo analisar a forma pela qual a questão social era abordada pelo Partido Republicano Rio-Grandense - PRR -, destacando o tratamento dispensado ao movimento operário e o discurso que permeava o partido no que concerne à questão social nos governos de Júlio de Castilhos e Borges de Medeiros. Para tanto, analisa elementos tanto de sua composição social quanto de sua relação com as oposições no estado, destacando uma série de características que conferem certa peculiaridade ao estado do Rio Grande do Sul durante a Primeira República. O foco principal do trabalho é, no entanto, a postura do governo do estado do Rio Grande do Sul diante da eclosão dos diferentes movimentos grevistas ocorridos entre os anos de 1895 e 1919.
\end{abstract}

PALAVRAS-CHAVE: Positivismo - Greves - Classe Operária

ABSTRACT: This article has as objective to analyze the form for which the social matter was boarded for the Partido Republicano Rio-Grandense - PRR - detaching the treatment excused to the working-class movement and the speech that the party with respect to the social matter in the governments of Júlio de Castilhos and Borges de Medeiros. In such a way analyzes elements of its social composition how much of its relation with the oppositions in the state, detaching a series of characteristics that confer certain peculiarity to the state of the Rio Grande do Sul during the First Republic. The main focus of the work is, however, the position of the government of the state of the Rio Grande do Sul ahead of the different movements strikers occurred between the years of 1895 and 1919.

KEYWORDS: Positivism - Strikes - Working Class

Na Primeira República, alçou-se ao poder no estado do Rio Grande do Sul um partido ideologicamente diferente dos demais partidos republicanos da federação: o PRR. Este partido estava permeado pelo ideário positivista, o que lhe conferia uma série de características peculiares e se refletia na própria organização política do estado, especialmente no tocante ao tratamento dispensado à questão social e aos movimentos grevistas. A análise da postura do Partido Republicano Rio-grandense perante os trabalhadores organizados exige, antes de tudo, que sejam definidos e apresentados uma série de elementos de sua contextualização histórica, sem os quais o entendimento desta relação seria impossível. Assim, em um primeiro ponto serão analisadas as principais características do PRR, e em um segundo ponto procurar-se-á compreender a forma como o PRR se relacionava com o movimento operário. Para Céli Pinto, o PRR foi um partido

\footnotetext{
* Doutorando em História da Universidade Federal do Rio Grande do Sul.
} 
qualitativamente diferente dos demais, pois "não era composto pela elite tradicional do estado; não era liberal, mas positivista, o que determinava uma percepção específica da questão pública". ${ }^{1}$ Estes elementos serão examinados de forma sintética e privilegiando os pontos que interessam ao tema deste trabalho, visto que a historiografia conta com uma série de obras que se aprofundaram nesta direção. ${ }^{2}$

\section{O Partido Republicano Rio-grandense de Castilhos a Borges de Medeiros: breve HISTÓRICO, CARACTERÍSTICAS E INFLUÊNCIAS POSITIVISTAS}

Após a instauração do regime republicano no país, alcançou o poder no estado do Rio Grande do Sul um partido numericamente inferior aos demais, mas que apresentava uma série de características que the conferiam grande relevância, tais como uma estruturação ideológica distinta, uma rígida disciplina partidária e uma atuação política que contemplava, para a sua manutenção no poder, a desestruturação das oposições. ${ }^{3}$ Esta inferioridade numérica do PRR fez com que, ao subir ao poder, o partido passasse a tomar medidas consideradas na época como sendo de "excessiva intransigência, banindo de todas as funções públicas e eletivas aqueles que por atos ou palavras não aderiram francamente ao novo regime". ${ }^{4}$ Estas medidas se justificavam pela "necessidade de engrossar as fileiras do partido republicano, bastante fraco em número". ${ }^{5}$

\footnotetext{
1 PINTO, Céli Regina. Positivismo: um Projeto político Alternativo (RS:1889-1930). Porto Alegre: L\&PM, 1986. p. 15.

${ }^{2}$ Ver por exemplo: LOVE, Joseph. O Regionalismo Gaúcho e as Origens da Revolução de 30. São Paulo: Perspectiva, 1975.; PINTO, Céli Regina. Positivismo: um Projeto político Alternativo (RS:1889-1930). Porto Alegre: L\&PM, 1986.; PESAVENTO, Sandra J. 'República Velha Gaúcha: Estado Autoritário e Economia'. In: DACANAL, J.H.(org.). RS: Economia e Política. Porto Alegre: Mercado Aberto, 1979.; FÉLIX, Loiva Otero. Coronelismo, Borgismo e Cooptação Política. 2ªed, Porto Alegre: Editora da Universidade/UFRGS, 1996.; FLORES, Élio Chaves. No Tempo das Degolas - Revoluções Imperfeitas. Porto Alegre: Martins Livreiro, 1996.; TRINDADE, Hélgio. Aspectos Políticos do Sistema Partidário Republicano Rio-Grandense (1882-1937). In: DACANAL, José Hildebrando (org.). RS: Economia e Política. Porto Alegre: Mercado Aberto, 1979.; ANTONACCI, Maria Antonieta. RS: as oposições e a revolução de 1923. Porto Alegre: Mercado Aberto, 1981.

3 SANTO, Miguel Frederico Espírito. O PRR e a Captura do Poder. In: FLORES, Hilda Agnes Hübner (org.). Revolução Federalista. Porto Alegre: Martins Livreiro / Nova Dimensão, 1993.

4 ESCOBAR, Wenceslau. 30 Annos de Ditacdura Rio-Grandense. Rio de Janeiro: Canton e Beyer, 1922. p. 20.

${ }^{5}$ ESCOBAR, Wenceslau. Op. cit. p. 21.
} 
Nos momentos posteriores à proclamação da República, à qual o povo assistiu "bestializado" ${ }^{6}$, o Governo Provisório do estado foi oferecido a Júlio de Castilhos, chefe do PRR que, temendo uma tentativa de restauração monárquica, indicou ao cargo o Marechal Visconde de Pelotas que, por sua vez, o nomeou Secretário Geral do Governo Provisório. Ao contrário dos demais estados brasileiros, a implantação do regime republicano não foi algo automático, uma vez que se nos outros estados os partidos republicanos eram compostos pelo conjunto de suas elites tradicionais, no Rio Grande do Sul, o PRR além de ser numericamente inferior, não contava com o apoio destas elites.

Entre o momento da proclamação e o ano de 1897 dez presidentes governaram o estado, sendo que apenas dois deles eram membros do PRR. Castilhos foi indicado a Presidente do estado por duas vezes, recusando em ambas oportunidades, temendo a reação monarquista, preferindo indicar pessoas ligadas aos círculos militares, como Visconde de Pelotas e o General Falcão da Frota. Eleito em 5 de maio de 1891, Castilhos foi deposto quatro meses depois por apoiar o golpe militar do Marechal Deodoro da Fonseca, sendo que o governo do estado ficou sob a responsabilidade de um triunvirato formado por Manoel Luís Rocha Osório, João de Barros Cassal e Joaquim Francisco de Assis Brasil, governo este apelidado pelos republicanos de 'Governicho'. Com o apoio do exército, Júlio de Castilhos reassumiu o governo do estado em junho de 1892, tendo renunciado logo a seguir em favor de seu vice-presidente, Vitorino Monteiro, que ficaria encarregado de organizar uma nova eleição na qual Castilhos foi eleito presidente, governando o estado em um período conturbado - no qual teve que enfrentar uma guerra civil - mas que conseguiu sair fortalecido e passar o cargo, em 1898, para um correligionário e herdeiro político: Borges de Medeiros, que governará o estado até $1928 .^{7}$

O PRR, partido que se manteve no poder desde então, era o portador de uma proposta de sociedade claramente diferente daquela que até então vigorava no Brasil, a qual se caracterizava por um liberalismo no plano econômico e um conservadorismo no plano social, sendo que esta diferença de propostas torna-se mais clara na medida em que a

\footnotetext{
${ }^{6}$ Expressão tomada por José Murilo de Carvalho de Aristídes Lobo, manifestando seu desapontamento com a maneira pela qual havia sido proclamado o novo regime. CARVALHO, José Murilo de. Os Bestializados: o Rio de Janeiro e a República que não foi. São Paulo: Companhia das Letras, 1987, p. 9.

${ }^{7}$ Ver entre outros: LOVE, Joseph. O Regionalismo Gaúcho e as Origens da Revolução de 30. São Paulo: Perspectiva, 1975.; PINTO, Céli Regina. Positivismo: um Projeto político Alternativo (RS:1889-1930). Porto Alegre: L\&PM, 1986.; PESAVENTO, Sandra. História do Rio Grande do Sul. 7ạed., Porto Alegre: Mercado Aberto, 1994.; FLORES, Moacyr. História do Rio Grande do Sul. 3ed, Porto Alegre: Nova Dimensão, 1990.
} 
emergência de novos grupos sociais e a transformação da correlação de forças faziam com que se revelasse "a incompatibilidade entre a estrutura monárquica tal como se achava constituída e as novas alterações surgidas" ${ }^{8}$. Assim, o advento da república possibilitou a ascensão de um novo partido ao poder, tendo como conseqüência disto a emergência de uma nova linha política e ideológica que propunha uma concepção específica da sociedade. Esta concepção se caracterizava pela presença de alguns elementos que seriam o substrato de um projeto de sociedade erigido sob a influência do positivismo comteano. De modo geral, as idéias positivistas tiveram uma grande penetração no imaginário político da República Velha brasileira ${ }^{9}$, atraindo diversos setores da sociedade, particularmente os estudantes, os professores e os militares. "Progresso e ditadura, o progresso pela ditadura, pela ação do Estado, eis aí um ideal do despotismo ilustrado que tinha longas raízes na tradição luso-brasileira desde os tempos pombalinos do século XVIII". ${ }^{10}$

José Murilo de Carvalho ressalta que o fato de os militares aderirem às idéias positivistas "é extremamente irônico, de vez que, de acordo com as teses positivistas, um governo militar seria uma retrogradação social" ${ }^{11}$. Fausto, entretanto, salienta que "o positivismo, com sua ênfase na ação do Estado e na neutralização dos políticos tradicionais, continha uma fórmula de modernização conservadora do país, que era muito atraente para os militares". ${ }^{12}$ O Rio Grande do Sul foi o estado brasileiro em que os ideais positivistas mais se difundiram e onde esta influência aparece mais nitidamente. Carvalho justifica esta observação dizendo que "a tradição militar da região, o fato de os republicanos serem lá uma minoria que precisava de disciplina e coesão para impor-se, a menor complexidade da sociedade local em comparação com São Paulo e Rio de Janeiro talvez tenham contribuído para a adesão mais intensa às idéias políticas do positivismo". ${ }^{13}$

Foi neste contexto que havia sido fundado o Partido Republicano Rio-Grandense (1882), tendo como uma das principais bandeiras o positivismo, onde passou a destacar-se

\footnotetext{
8 PESAVENTO, Sandra. História do Rio Grande do Sul. 7ạed., Porto Alegre: Mercado Aberto, 1994. p. 64.

9 Sobre o positivismo no Brasil ver: LINS, Ivan. História do Positivismo no Brasil. 2ªed, São Paulo: Nacional, 1967.; RODRIGUES, Ricardo Vélez. Castilhismo: uma filosofia da república. Porto Alegre: Mercado Aberto, 1981.

${ }^{10}$ CARVALHO, José Murilo de. A Formação das Almas: O Imaginário da República no Brasil. São Paulo: Companhia das Letras, 1998. p. 27.

${ }^{11}$ CARVALHO, José Murilo de. A Formação das Almas: O Imaginário da República no Brasil. São Paulo: Companhia das Letras, 1998. p. 27.

12 FAUSTO, Bóris. História do Brasil. São Paulo: EdUSP/FDE, 1996. p. 232.

13 CARVALHO, José Murilo de. Op. Cit. 1998. p. 28.
} 
um de seus fundadores: Júlio de Castilhos. ${ }^{14}$ Love destaca que "como muitos de sua geração, Castilhos era discípulo ardoroso de Auguste Comte. O positivismo comtiano começara a penetrar no pensamento brasileiro na década de 1860 e, na época em que Castilhos chegou a São Paulo, fizera um número considerável de adeptos entre as escolas profissionais brasileiras". ${ }^{15}$

Aos poucos, Castilhos foi assumindo definitivamente a posição de chefe do partido, passando a exercitar sua doutrina que teria como ponto alto a elaboração da Constituição do estado. No entanto, como bem observa Escobar, "[Júlio de Castilhos] só aceitava do comtismo o que the convinha, o que se conformava com seu ponto de vista". ${ }^{16}$ Segundo este prócere da oposição gaúcha, "a política preconizada por Augusto Comte calhava perfeitamente a seus intuitos, porque sob fórmulas democráticas dissimulava a ditadura" ${ }^{17}$ Em 1898, Castilhos indicou Borges de Medeiros à Presidência do estado, ficando ele somente como presidente do partido. No entanto, as características fundamentais da linha política do partido foram mantidas, embora no plano político se verifiquem algumas mudanças, pois enquanto Castilhos vivera a conjuntura de instauração do novo regime, enfrentando uma oposição forte e organizada, com Borges a máquina governativa já estava moldada e a oposição não estava tão organizada quanto nos anos anteriores. Durante o período entre 1898 e 1903, embora Borges de Medeiros $^{18}$ fosse o Presidente do estado, vivia sob a sombra de Castilhos, de modo que se afirmava que quem realmente governava era o chefe do partido. ${ }^{19}$ Outro ponto que diferenciava a situação governativa enfrentada por Borges de Medeiros daquela apresentada no período de Castilhos é o progressivo recrudescimento do conflito entre capital e trabalho. Isto se deve, entre outros motivos, ao fato de que durante o governo de Castilhos o grau de organização dos operários ainda era

\footnotetext{
14 Sobre Júlio de Castilhos ver: FRANCO, Sérgio da Costa. Júlio de Castilhos e sua Época. Porto Alegre: Globo, 1967.; TODESCHINI, Cláudio (org.). Júlio de Castilhos. Porto Alegre: EMMA/SEC, DAC, IEL, 1978.; SOARES, Mozart Pereira. Júlio de Castilhos. 2ªed., Porto Alegre: IEL, 1996. (Rio Grande Político)

${ }^{15}$ LOVE, Joseph. O Regionalismo Gaúcho e as Origens da Revolução de 30. São Paulo: Perspectiva, 1975, p. 38.

16 ESCOBAR, Wenceslau. Op. Cit. p. 79.

17 ESCOBAR, Wenceslau. Op. Cit. p. 22.

18 Sobre Borges de Medeiros ver: FONTOURA, João Neves da. Borges de Medeiros e Seu Tempo. Porto Alegre: Globo, 1958. PESAVENTO, Sandra. Borges de Medeiros. 2a ed., Porto Alegre: IEL, 1996. Rio Grande Político.

${ }^{19} \mathrm{Na}$ sátira política sobre Borges de Medeiros intitulada Antônio Chimango de autoria de Ramiro Barcellos esta assertiva é evidenciada na seguinte passagem: "Um dia [Castilhos] chamou o Chimango / E disse: Escuta, meu rapaz, / Vais ser o meu capataz; / Mas, tem uma condição: / As rédeas na minha mão / Governando por detrás."
} 
incipiente, vindo a crescer gradativamente durante os longos anos do governo de Borges de Medeiros.

Uma das características que diferenciava o PRR dos demais partidos republicanos é o fato de que ele teve que se defrontar com uma oposição política organizada, sobretudo, porque ele não era composto pela elite tradicional do estado. Neste sentido, Pinto salienta que "a política rio-grandense na chamada República Velha diferenciou-se radicalmente das dos demais estados brasileiros. Enquanto nesses últimos os partidos republicanos regionais funcionaram como partidos únicos capazes de conterem dentro de seus limites toda a sorte de conflitos e interesses, no Rio Grande do Sul o PRR teve, ao longo de mais de 40 anos, de governar enfrentando um significativo movimento oposicionista". ${ }^{20}$

Esta característica manifesta-se também em relação à composição social do PRR: se seus membros faziam parte da elite pecuarista rio-grandense, não pertenciam "à tradicional elite pecuária da campanha gaúcha, que quase em sua totalidade formava o Partido Liberal. Eram na maioria pertencentes à região norte do estado, de ocupação recente e mais pobre que a campanha, quer pela ausência da indústria do charque, quer pela distância dos centros consumidores". ${ }^{21}$ Deste modo, o PRR necessitou um maior respaldo de outros segmentos sociais, incorporando demandas e logrando o êxito de promover um alargamento de sua base social, incluindo nela o colonato de origem imigrante e os elementos ligados à indústria e ao comércio, setores médios urbanos da sociedade suscetíveis à influência positivista defendida pelo partido e que, entre outros traços, se caracterizava pela busca de austeridade moral e social.

Este alargamento das bases fez com que o partido tivesse que atender a um grande leque de demandas originárias de vários segmentos sociais, o que fazia com que o Estado se apresentasse como o "representante de todos os grupos sociais". ${ }^{22}$ Colaborava para isto a concepção positivista de que o Estado deveria ser extremamente técnico, descaracterizando e ocultando sua natureza fundamentalmente política. O Estado deveria promover com equilíbrio o desenvolvimento de todas as classes sociais indiscriminadamente, gerando a noção de um "Estado que - como portador de interesses gerais - intervinha na sociedade

\footnotetext{
20 PINTO, Céli Regina. A Política Rio-Grandense na República Velha - a Percepção das Oposições. Análise Econômica. Março/1987. Ano 5, n. 8, p. 83.

${ }^{21}$ PINTO, Céli Regina. Positivismo: um Projeto Político Alternativo. Porto Alegre: L\&PM, 1986. p. 10.

22 PESAVENTO, Sandra J. História do Rio Grande do Sul. 7ạed, Porto Alegre: Mercado Aberto, 1994. p. 68.
} 
para atingir uma harmonia social, que no limite procurava integrar o proletariado na sociedade moderna". ${ }^{23}$

Este aspecto da política gaúcha fez com que a fração da classe dominante que subira ao poder tivesse que manter afastada do mesmo a oposição, utilizando-se tanto da ampliação de sua base social quanto de meios como a força e a fraude eleitoral, estimulada pelo princípio positivista de "viver às claras", o que em última análise era um dispositivo de controle sobre os votos dos eleitores uma vez que durante o período no qual o PRR se manteve no poder dentro do estado, “o exercício do voto [...] é 'livre e público' quer o proferido nas suas urnas pelo eleitorado, quer no júri pelos juízes, quer nas assembléias representativas', o que oferecia na prática uma poderosa arma de coerção política nas mãos dos coronéis burocráticos [...]. ${ }^{24}$

As idéias políticas do positivismo passaram a ter um papel de grande relevância tanto nos discursos quanto nas ações do partido, inclusive no que se refere à relação do governo com os trabalhadores em geral. Entre estas idéias positivistas incorporadas ao discurso do PRR, algumas delas devem ser destacadas devido à relação que mantém com o tema aqui abordado.

\section{A concentração de poderes}

No que tange à concentração de poderes, através de uma Constituição estadual que esvaziava as atribuições da Assembléia dos Representantes, o PRR concentrava uma grande soma de poderes nas mãos do Presidente do estado, que não só dirigia o executivo como também promulgava as leis. ${ }^{25}$ A Assembléia tinha unicamente a função de "votar os orçamentos, sobre o projeto que o chefe do governo lhe apresentar, muni-lo dos instrumentos de crédito, para as despesas que ele mesmo lhe houver proposto, e decretar os meios necessários aos serviços, que esse poder onigênero, nas leis de sua própria

\footnotetext{
23 ANTONACCI, Maria Antonieta. RS: as Oposições e a Revolução de 1923. Porto Alegre: Mercado Aberto, 1981. p. 20.

24 TRINDADE, Hélgio. Aspectos Políticos do Sistema Partidário Republicano Rio-Grandense. In: DACANAL, J. H. e GONZAGA, Sérgio (Org.). RS: Economia e Política. Porto Alegre: Mercado Aberto, 1979. p. 124.

${ }^{25}$ Wenceslau Escobar ironicamente afirmava que "este 'primeiro monumento de sabedoria do ocidente', como Ihe chamavam os comtistas, era e continua a ser a mais completa negação do regime republicano, porque sob a máscara democrática, concentra todos os poderes em mão do executivo, arvorando seu representante em perfeito ditador". ESCOBAR, Wenceslau. Op. Cit. p. 24.
} 
gestação, tiver instituído". ${ }^{26}$ Através da Constituição de 1891 percebe-se que o Presidente do estado tinha atribuições que expressam este alto nível de concentração de poder. Entre estas atribuições destacam-se os artigos que conferem ao Presidente do estado a faculdade de (1ㅇ) promulgar as leis, que, conforme as regras adiante estabelecidas, forem da sua competência; (4ํ) expedir decretos, regulamentos e instruções para a fiel e conveniente execução das leis; (18) declarar sem efeito as resoluções ou atos das autoridades municipais, quando infringirem leis federais ou do Estado; (10) organizar a força pública do Estado, dentro da verba orçamentária destinada a este serviço, dispor dela, distribuí-la e mobilizá-la conforme as exigências da manutenção da ordem, segurança e integridade do território; entre outras. ${ }^{27}$

Como pode ser observado, a concentração de poderes perpassava as mais diversas esferas da administração pública e acabava conseqüentemente por se refletir também nas relações entre o Estado e o movimento operário. O Estado onipotente servia-se destes meios para intervir na esfera das relações entre capital e trabalho nas circunstâncias em que a solução entre as partes envolvidas parecesse distante. No artigo 10 da Constituição, acima citado, percebe-se que o governo tem o direito de utilizar a força pública do estado toda vez que as exigências de manutenção da ordem assim o necessitarem. Assim, a força pública foi freqüentemente acionada para atuar em greves e meetings em nome da manutenção da ordem, o que implica dizer que para o governo a questão social era um momento de desordem pública que exigia a atuação de força policial. Além disso, outros três artigos da Constituição estão relacionados aos mecanismos de repressão à disposição do Estado: o $11 \%$, o 12 을 o o 14ㅇ․

Rui Barbosa, um dos principais críticos da Constituição rio-grandense, argumentava que "o sistematismo positivista não se podia realizar em uma fórmula mais dura, mais opressiva, mais radicalmente inconciliável com as idéias comuns a todos os governos constitucionais, a todas as constituições republicanas, a todas as repúblicas federativas. Todas elas, uma a uma, repelem o autocratismo dessa organização, essa democracia cesariana, que concentra numa só entidade, com a prerrogativa de executar a lei, a de fazer, e admite a investidura do governo em um magistrado eleito pelo arbítrio de um homem,

\footnotetext{
26 BARBOSA, Rui. Ruínas de um Governo. In: Obras Completas. 1913. VI. p. 79.

27 OSÓRIO, Joaquim. Constituição Política do Estado do Rio Grande do Sul: Comentário. Brasília: UnB, 1981. p. 117-138.
} 
sem intervenção dos sufrágios populares". ${ }^{28} \mathrm{O}$ alto nível de concentração de poderes nas mãos do Presidente do estado era também uma forma de o Executivo conseguir implementar suas idéias em um estado em que o partido no poder não possuía a maioria eleitoral, apelando para o esvaziamento das funções da Assembléia dos Representantes para não correr o risco de ter que enfrentar uma oposição legislativa que viesse a obstaculizar suas propostas de governo.

O governo dos mais capazes

O segundo elemento destacado anteriormente - a exclusão dos agentes sociais subalternos enquanto sujeitos efetivos da ação política sobre a sociedade, ficando a mesma sob a tutela dos mais capazes - é percebido nitidamente à medida que o ideário adotado pelo PRR apregoa uma subordinação da coletividade aos princípios regidos pelas leis naturais - influência do positivismo comteano - que determinam que aos mais capazes sejam atribuídas as funções de liderança dentro do organismo social uma vez que a sociedade é regida por "leis naturais de concentração do poder e da riqueza". ${ }^{29}$ Assim, "o positivismo não reconhece a ninguém outro direito senão o de cumprir o seu dever. 0 positivismo não admite nunca senão deveres de todos para com todos; pois que seu ponto de vista sempre social não pode comportar nenhuma noção de direito, constantemente fundada na individualidade" ${ }^{30}$

Flores destaca que um importante elemento para a perpetuação do PRR no poder é seu monopólio partidário, o que tem como conseqüência a obstaculização dos instrumentos que pudessem levar ao poder outros grupos ou partidos. O autor salienta que "a opção pela ditadura científica e pelo regime sociocrático fez nascer, no grupo castilhista, senão um desprezo político, ao menos uma consciência de insignificância participativa por parte dos agentes sociais subalternos da estrutura social rio-grandense" ${ }^{31}$ Esta concepção de que os mais capazes e competentes deveriam concentrar os esforços em benefício da sociedade,

\footnotetext{
28 BARBOSA, Rui. Op. Cit. p, 78.

${ }^{29}$ COMTE, Augusto. Apud LOWY, Michael. As Aventuras de Karl Marx contra o Barão de Münchhausen. 5aed, São Paulo: Cortez, 1994. p. 24.

${ }^{30}$ COMTE, Auguste. O Catecismo Positivista. In: Os Pensadores. São Paulo: Abril Cultural, 1973. v. 33. p. 263.

31 FLORES, Élio Chaves. No Tempo das Degolas - Revoluções Imperfeitas. Porto Alegre: Martins Livreiro, 1996. p. 51.
} 
sendo eles os principais agentes do progresso, fica clara quando Borges de Medeiros, ao assumir o poder em 1898, afirma que o Estado deve "instituir o poder temporal sobre a base de um legítimo regime presidencial assente na plena confiança dos governados e inteira responsabilidade dos governantes". ${ }^{32}$ Deste modo, vê-se que o princípio comteano de que o positivismo só reconhece às pessoas o direito de cumprir o seu dever fica incorporado ao discurso republicano, na medida em que a plena confiança dos governados nos governantes pode ser entendida como a plena subserviência às ordens dos superiores. O "positivismo atraía os modernizadores conservadores, que desejavam os benefícios do progresso material sem prejuízo da hierarquia social: Comte parecia oferecer um modelo de desenvolvimento sem mobilização social". ${ }^{33}$

Um modelo de desenvolvimento sem mobilização social, sem a quebra das hierarquias sociais, permitiria a manutenção e a conservação da própria estrutura social e excluiria deste processo a participação das classes trabalhadoras e, particularmente, do operariado. Fica clara esta afirmação quando se observa que o sustentáculo do poder temporal se dá através da confiança dos governados para com os governantes, estes sim os agentes do desenvolvimento. A mobilização social de camadas mais amplas da população seria um risco para o rompimento da ordem e este é um conceito muito caro aos republicanos gaúchos. Flores salienta que "o papel das classes baixas é ser mero apoio e a sua participação tende a ser mais emocional-instantânea do que racional-legal". ${ }^{34}$

\section{A continuidade político-administrativa: disciplina partidária e natureza conservadora}

Após a morte de Castilhos, em 1903, Borges de Medeiros ${ }^{35}$ fez questão de reafirmar que os princípios positivistas adotados por Castilhos continuariam a ser por ele seguidos. Em sua mensagem à Assembléia dos Representantes no ano de 1904, afirma que "observando escrupulosa lealdade para com os compromissos do passado, assim como severa intransigência na afirmação quotidiana dos princípios, o PRR, força indestrutível e

\footnotetext{
32 Mensagem do Presidente do Estado à Assembléia dos Representantes. 1898.

33 LOVE, Joseph. O Regionalismo Gaúcho e as Origens da Revolução de 30. São Paulo: Perspectiva, 1975. p. 38.

34 FLORES, Élio Chaves. Op. Cit. p. 57.

${ }^{35}$ Que governará o estado até 1928 com um breve intervalo quando indicou Carlos Barbosa para a presidência com o intuito de reorganizar o partido e outro quando, por motivo de saúde, o estado foi governado pelo vice Salvador Ayres Pinheiro Machado entre 1915 e 1917
} 
conservadora no seio da república, continua a reger-se pelos moralizadores processos de sua doutrina orgânica". ${ }^{36}$ Nesta passagem, denotam-se alguns pontos importantes de serem mencionados: o primeiro deles refere-se ao fato de Borges de Medeiros demonstrar a preocupação com a permanência dos preceitos adotados por Castilhos, reafirmando uma continuidade de ações e de princípios. Outro ponto importante está relacionado à constante afirmação da natureza conservadora do PRR e seus rígidos princípios morais.

Com relação ao primeiro ponto - a continuidade de ações e de princípios - é interessante perceber que, após a morte de Castilhos, Borges busca, através da figura do grande líder e de seus princípios, estabelecer um elemento de continuidade para o partido. Mesmo antes de sua morte, Borges de Medeiros já fundava a legitimidade de sua autoridade pública sobre a insígnia da continuidade política e administrativa ante seu predecessor. $\mathrm{Na}$ mensagem à Assembléia dos Representantes do ano de 1898, fazia a afirmação de que haveria "de manter a mesma continuidade de vistas e de ação, da qual depende essencialmente todo progresso como desenvolvimento lógico da ordem". ${ }^{37}$

No entanto, após a morte de Castilhos, esta continuidade será invocada com mais freqüência e com mais veemência. ${ }^{38}$ De tal modo era exaltada a grandeza de Júlio de Castilhos que se chegava ao extremo de afirmar que "embora morto, parecia que continuava à frente de seus partidários, respeitado e temido". ${ }^{39}$ Exageros à parte, o que se percebe é que a unidade partidária e a legitimidade de mando conferida a Borges de Medeiros passam diretamente pela menção ao nome e à grandeza de Castilhos. Este fato se vê continuamente, sobretudo nos editoriais d'A Federação. Em um desses editais o articulista salienta que o PRR "está forte porque é disciplinado; esmaga as ambições pessoais, porque tem doutrinas a sustentar; é coeso, porque obedece a chefia capaz e acatadíssima de um abnegado continuador da obra do excelso Castilhos". ${ }^{40}$ Neste trecho, Borges de Medeiros é apresentado como sendo o continuador da obra de Castilhos, invocando uma perspectiva de

\footnotetext{
36 Mensagem do Presidente do Estado à Assembléia dos Representantes. 1904.

37 Mensagem do Presidente do Estado à Assembléia dos Representantes. 1898.

38 Sobre a construção mítica de Júlio de Castilhos ver: FÉLIX, Loiva Otero. A Fabricação do Carisma: A Construção Mítico-Heróica na Memória Republicana Gaúcha. In: FÉLIX, Loiva e ELMIR, Cláudio (org.). Mitos e Heróis: Construção de Imaginários. Porto Alegre: Editora da Universidade, 1998.; ALBECHE, Daysi Lange. Imagens do Gaúcho: História e Mitificação. Porto Alegre: EdiPUCRS, 1996.

39 VELLINHO, Moysés. Castilhos e o Castilhismo. In: TODESCHINI, Cláudio (org.). Júlio de Castilhos. Porto Alegre: EMMA/SEC, DAC, IEL, 1978, p. 49.

${ }^{40}$ A Federação. Porto Alegre: 27/07/1915. p. 03.
} 
continuidade ao mesmo tempo em que ressalta a força do PRR, conseqüência de uma negação das ambições pessoais em favor de um projeto partidário mais amplo.

A disciplina interna do partido também era destacada, e esta estaria baseada em uma dedicação personalista às indicações do líder. Aliás, a disciplina partidária é um dos elementos que melhor caracterizaria o PRR como organização política. Love chega a destacar que o partido se constituía em uma "arregimentada organização" ${ }^{41}$ e que era "hermeticamente fechado". ${ }^{42}$ O mesmo autor salienta que, apesar do Presidente do estado ter através da Constituição estadual um poder de mando equivalente a um governo ditatorial, "era importante a cobertura de um partido disciplinado e, para ter esta disciplina, seu chefe dispunha de quatro elementos: o poder do Governador de cancelar as eleições municipais ou de interferir na política local por outras vias e mediante decreto; o controle dos assuntos partidários em nível local, através de coronéis leais exclusivamente a ele; a capacidade dos coronéis de mobilização dos votos em seus distritos; e a eficiência da poderosa Brigada Militar estadual, que podia ser empregada para fins políticos" ${ }^{43}$ O papel da Brigada também pode ser invocado tendo em vista esta disciplina partidária, sobretudo no que se refere às suas conseqüências sobre o tratamento da questão social, visto que foi com muita freqüência acionada no sentido de reprimir as manifestações de trabalhadores, empregando muitas vezes violência física contra manifestantes. Tendo em vista a mencionada eficiência da Brigada Militar e a sua obediência às determinações governamentais, pode-se inferir que nestas ocasiões os soldados estavam cumprindo ordens de seus superiores e, através deles, o partido estava pondo em prática sua política em relação aos "distúrbios" sociais. Mesmo quando a ação dos soldados se apresentava de modo violento contra os manifestantes, esta ação não era alvo de censura dos seus superiores. Pelo contrário, durante a greve de 1919, a Brigada Militar repreendeu de modo bastante violento os grevistas e inclusive ganhou uma menção no relatório de Borges de Medeiros à Assembléia dos Representantes que elogiou o "modo enérgico e eficaz" ${ }^{44}$ com que ela se conduziu naquela ocasião.

\footnotetext{
41 LOVE, Joseph. Op. Cit. p. 61.

42 LOVE, Joseph. Op. Cit. p. 78.

43 LOVE, Joseph. Op. Cit. p. 83.

44 Mensagem do Presidente do Estado à Assembléia dos Representantes. 1920.
} 
O segundo ponto a ser abordado - a natureza conservadora do PRR - é um dos princípios mais freqüentes em seu discurso, de modo que o jornal $A$ Federação considera o partido como tendo "consigo a quase unanimidade eleitoral do Rio Grande do Sul porque é a força conservadora das tradições do Estado, a cujos destinos preside com alta sabedoria e real sólido proveito para o progresso desta terra, a sombra da mais ampla liberdade e garantia de todos os direitos". ${ }^{45}$ De fato, esta quase unanimidade eleitoral de que trata o editorial deve ser relativizada, visto que "apesar de todas as forças em seu comando, o PRR não pode manter seu monopólio de poder sem a intimidação, a violência e a fraude" ${ }^{46}$

O caráter conservador do PRR também se estende à estreita relação advogada pela doutrina positivista entre a conservação da ordem e o desenvolvimento do progresso material, o que é de fato extremamente importante para o Partido Republicano. Borges de Medeiros destaca como sendo a principal tarefa pública "a elementar função de conservar a paz pública como supremo bem social” ${ }^{\prime 4}$, sendo que o governo não medirá esforços no intuito de manter as classes subalternas sob controle, a fim de manter a ordem. Isto se verá tanto no governo Castilhos quanto no de Borges de Medeiros, visto que ambos buscam até o limite, através da utilização da força pública, coibir as manifestações operárias consideradas perigosas para o progresso da sociedade. Deste modo, o PRR, inspirado no positivismo, entende "o progresso como desdobramento da ordem" ${ }^{48}$

É interessante perceber que o PRR pretendia implementar uma modernização econômica nos moldes de um desenvolvimento capitalista a partir, principalmente, de uma diversificação da produção local, do fortalecimento do mercado interno e da ampliação qualitativa e quantitativa da rede de transportes. Paradoxalmente a esta face modernizadora do PRR no aspecto econômico, o partido demonstrava no plano social um conservadorismo que se expressava, sobretudo, através da máxima positivista considerada pelo partido como uma "divisa orgânica - conservar melhorando". ${ }^{49}$ Este princípio pressupõe "o progresso como desenvolvimento lógico da ordem" ${ }^{50}$, sendo o dever supremo do Estado a manutenção da mesma. Pesavento já destacara este paradoxo ao afirmar que "a

\footnotetext{
${ }^{45}$ A Federação. Porto Alegre: 27/07/ 1915. p. 03.

46 LOVE, Joseph. O Regionalismo Gaúcho e as Origens da Revolução de 30. Op. Cit. p. 84.

47 Mensagem do Presidente do Estado à Assembléia dos Representantes. 1898.

${ }^{48}$ Mensagem do Presidente do Estado à Assembléia dos Representantes. 1904.

49 Mensagem do Presidente do Estado à Assembléia dos Representantes. 1903.

50 Mensagem do Presidente do Estado à Assembléia dos Representantes. 1898.
} 
visão positivista era progressista e conservadora ao mesmo tempo, ou seja, pretendia conciliar o progresso econômico com a conservação da ordem social" ${ }^{51}$

\section{A incorporação do proletariado à sociedade moderna}

Outro ponto mencionado anteriormente e que se encontra permanentemente veiculado pelo discurso do PRR é o que concerne à incorporação do proletariado à sociedade moderna, princípio positivista que, como tantos outros, permeia o discurso e a ação do partido. No entanto, não está dito realmente de que modo se daria esta incorporação do proletariado uma vez que ela está vinculada a uma série de pressupostos que atribuem a responsabilidade de atuar sobre a sociedade aos indivíduos "mais capazes", excluindo a possibilidade de uma incorporação integral, que abranja também participação e igualdade de direitos. Um articulista do jornal A Federação, Renato Costa, escreve que seria dever do Estado zelar pelo operariado, "integrando-o em toda a sua finalidade histórica" 52 , sendo que é possível interpretar qual seria o significado de "integrar o operariado em sua finalidade histórica" através da observação dos preceitos positivistas defendidos pelo PRR, sobretudo quando se percebe que Comte considerava que os operários deveriam ser preparados para "respeitarem e mesmo reforçarem as leis naturais da concentração do poder e da riqueza". ${ }^{53}$ Estas "leis naturais", que consistem na "indispensável concentração das riquezas entre os chefes industriais" ${ }^{\prime \prime 4}$, deveriam ser asseguradas através da "ativa participação dos exércitos propriamente ditos na sustentação permanente da ordem pública". ${ }^{55}$ Percebe-se que o discurso que advoga a incorporação do proletariado à sociedade moderna traz oculta uma parte da concepção positivista de natureza conservadora e contrária a qualquer tipo de mudança na ordem social que, apesar de não estar exposta nos pronunciamentos e manifestações ao público, está presente na forma do PRR atuar na solução da questão social.

\footnotetext{
51 PESAVENTO, Sandra. História do Rio Grande do Sul. 7ạ ed., Porto Alegre: Mercado Aberto, 1994. p. 67.

52 Os Operários em Face das Leis do Estado. In: A Federação. Porto Alegre. 1/01/1922. p. 01.

53 COMTE, Augusto. Apud LOWY, Michael. As Aventuras de Karl Marx contra o Barão de Münchhausen. 5ạed, São Paulo: Cortez, 1994. p. 24.

54 COMTE, Augusto. Op. Cit. p. 24.

55 COMTE, Augusto. Ibidem. p. 59.
} 


\section{O PARTIDO REPUBLICANO RIO-GRANDENSE E O TRATAMENTO DA QUESTÃO SOCIAL}

Após ter analisado as principais características do PRR e as influências positivistas por ele incorporadas, serão examinados especificamente alguns aspectos que dizem respeito ao tratamento que o PRR dispensava à questão social, privilegiando nesta análise os momentos em que o antagonismo caracterizado pelo progressivo estabelecimento da luta de classes - nos limites possíveis de uma sociedade oligárquica e com uma industrialização ainda incipiente - se projeta de forma mais visível. Pode-se afirmar que os seguintes procedimentos específicos são característicos da forma com a qual o PRR se relacionava com os trabalhadores:

- privatismo nas relações entre capital e trabalho;

- paternalismo nas relações com os trabalhadores;

- repressão às manifestações de trabalhadores, entendidas como desordem social;

- tentativa de generalizar uma visão de harmonia social que buscasse obscurecer a existência de conflitos sociais na sociedade gaúcha.

\section{Privatismo nas relações sociais entre capital e trabalho}

O princípio do privatismo aplicado às relações de trabalho é um dos pontos mais enfatizados pelo PRR, sendo que o mesmo sugere que os conflitos entre patrões e trabalhadores deveriam ser resolvidos através de negociações entre eles próprios, sem uma ingerência significativa por parte do Estado. Este privatismo compreende a perspectiva da não-intervenção governamental nas questões que envolvem as diferenças entre patrões e empregados, privilegiando o entendimento direto entre as partes de modo que "com bases de boa política, será desse modo absurda a intervenção do Estado, a ação dos poderes públicos, a não ser conciliatoriamente, em casos de urgência decisiva, por ocasião de reclamações ou conflitos possíveis de conciliar, sem outro instrumento senão o do conselho puro, como é convicção e pensamento de S. Ex.a. o Dr. Borges de Medeiros." ${ }^{256}$

\footnotetext{
${ }^{56}$ A Federação. Porto Alegre: 10/05/1919. p. 05.
} 
As linhas gerais propostas pelo partido para a conduta do Estado nestes casos estão sumariamente expostas no Programa do Partido Republicano Rio-Grandense. O Programa afirmava que o Estado deveria eximir-se de atuar nos conflitos entre patrões e empregados, a não ser em situações extremadas e ainda assim sob a forma de mediador das negociações para que estas chegassem a um bom termo, através de um "tribunal de arbitragem para resolver os conflitos entre patrões e empregados" ${ }^{57}$ Este princípio, que remete ao marco fundador do PRR, é ainda vigente em 1918 quando, por ocasião de uma greve em Porto Alegre, o Estado defendia o privatismo nas relações entre capital e trabalho e sustentava que "não pode a classe operária esperar mais dos poderes públicos, devendo a solução das questões deste gênero, que se suscitarem entre patrões e empregados, ser afeita a uma autoridade espiritual de um árbitro, quando não seja obtida por acordo das próprias partes interessadas". ${ }^{58}$

Tanto o Programa quanto a ação política do partido deixam claro que as questões entre capital e trabalho deveriam ser solucionadas entre as partes interessadas, cabendo ao Estado tão somente atuar como mediador das negociações entre ambas. Segundo o discurso do PRR, o privatismo deveria prevalecer nas relações entre capital e trabalho de modo que ao Estado caberia tão somente fornecer o exemplo para que os empresários capitalistas procurassem agir da mesma forma ou agir de árbitro em casos em que a negociação diretamente entre as partes estivesse difícil. Deste modo, o tratamento dispensado pelo Estado a seus servidores deveria repercutir nas relações entre os agentes privados, ou seja, "o Estado oferece o exemplo" ${ }^{59}$ ao particular através do item "J" das "Teses Sociais" do Programa, onde se determina que "ficam suprimidas quaisquer distinções entre os funcionários públicos do quadro e os simples jornaleiros, estendendo-se a estes as vantagens de que gozem aqueles". ${ }^{60}$

O Programa transmite a idéia de que "concorre assim o governo, quanto às suas relações com o proletariado a serviço do Estado para a solução do problema social. Cumpre,

\footnotetext{
57 Programa Político do Partido Republicano Rio-Grandense. Apud. OSÖRIO, Joaquim Luís. Partidos Políticos no Rio Grande do Sul: Período Republicano. Livraria do Globo. 1930, p. 50.

${ }^{58}$ A Greve Fracassada - A Eficácia das Medidas do Governo. A Federação. Porto Alegre: 23.07.1918. p. 01.

59 OSÓRIO, Joaquim Luís. Partidos Políticos no Rio Grande do Sul: Período Republicano. Livraria do Globo, 1930, p. 31.

60 Programa Político do Partido Republicano Rio-Grandense. Apud. OSÓRIO, Joaquim Luís. Op. Cit. p. 49.
} 
agora, ao particular, que representa o capital, por sua vez, para a solução do problema" ${ }^{61}$ "exemplo" fornecido pelo governo deveria ter um efeito pedagógico e fazer com que os capitalistas pudessem "com altruísmo tomar a iniciativa do assunto nas suas relações com os trabalhadores, para que seja o magno problema solucionado sem abalos, sem a intervenção de leis compressivas, muitas vezes perturbadoras. Demais, deve o particular contar com o indispensável concurso do Estado para esta obra humana". ${ }^{62}$

Além de atuar eventualmente como mediador nos conflitos sociais que se apresentassem, o Estado se reservava o direito de sensibilizar as "classes capitalistas" para a questão social, dando o exemplo necessário para fazer com que o conflito de classes fosse amenizado. A aparente contradição existente entre o privatismo e o paternalismo pode ser mais bem entendida através de uma breve observação da bancada gaúcha no Parlamento Nacional, uma vez que esta se opunha constantemente aos projetos destinados a regulamentar as relações de trabalho, garantindo o privatismo e o livre entendimento nestas relações, mas propunha projetos que representassem indenizações ao trabalhador em casos de acidente. Entre os anos de 1918 e 1919 percebe-se uma posição divergente entre os representantes gaúchos e os paulistas, pois quando estes apresentaram uma proposta de regulamentação do trabalho no Congresso os representantes gaúchos se posicionaram contra e, com o apoio da bancada de outros estados, conseguiram que os paulistas retirassem tal proposta. Por outro lado, no início de 1919 os gaúchos apresentaram um projeto que previa o pagamento de indenizações pelos empresários em casos de acidente de trabalho enquanto os paulistas se opunham a esta iniciativa, prevalecendo no final a posição da bancada gaúcha, que conseguiu transformar o projeto em lei. ${ }^{63}$

\section{Paternalismo nas relações com os trabalhadores}

Outro ponto que caracteriza a posição do PRR em relação aos trabalhadores é o paternalismo, o que implica dizer que o governo entendia e buscava transmitir a idéia de

\footnotetext{
61 OSÓRIO, Joaquim. Op. Cit. 1930. p. 31-32.

62 OSÓRIO, Joaquim. Op. Cit. 1930. p. 32.

63 PETERSEN, Sílvia. As greves no Rio Grande do Sul. In: DACANAL, J.H. e GONZAGA, Sérgius (Org.). RS: Economia e Política. Porto Alegre: Mercado Aberto, 1979. p. 280.
} 
que o trabalhador encontrava-se sob a "mais ampla tutela benéfica do Estado" ${ }^{64}$ Esta "tutela benéfica" sob a qual os trabalhadores estavam colocados gerava o entendimento de que os mesmos deveriam ser gratos ao governo que, de modo paternalista, buscava suprir e atender as demandas dos trabalhadores que fossem consideradas legítimas. Este entendimento gera também a idéia de que os trabalhadores deveriam esperar que suas necessidades fossem supridas pelo governo de modo que, estando o trabalhador sob a proteção benéfica do Estado, seria desnecessário que o mesmo procurasse se mobilizar e arregimentar a fim de reivindicar direitos através de greves e de outros meios.

A postura assumida pelo governo em relação às greves era de condenação, visto que as caracterizava como "paredes anárquicas que visam perverter a ordem social e desrespeitar a liberdade". ${ }^{65}$ Para o governo, as greves não seriam o melhor caminho para os trabalhadores obterem as vantagens e melhorias que desejavam. O órgão oficial do partido, A Federação, destaca que o operariado estaria sendo levado a tomar medidas que o prejudicariam com a eclosão de greves e que

"do modo como está sendo encaminhada esta questão do trabalho sob a direção de homens que não tem a nítida compreensão dos fenômenos sociais, o proletariado está prejudicando a sua causa, atraindo sobre si os ódios da sociedade, ao invés de conquistar as simpatias de que é digno pela sua função eminentemente social e respeitável" ${ }^{66}$

Nesta passagem, o governo volta a criticar as lideranças operárias, afirmando que as mesmas não têm a nítida compreensão dos fenômenos sociais, de modo que para a solução dos mesmos deveria contar com a proteção do Estado. Esta tentativa de atingir a credibilidade das lideranças operárias passa pela afirmação de que o operariado nacional, ingênuo e crédulo, estaria sendo manipulado por imigrantes que só queriam semear a discórdia e a desordem, sendo que o governo do estado seria responsável por "um fim muito nobre e humano: o de contribuir para emancipar os trabalhadores honrados e de boa fé da tutela revolucionária e anarquizadora dos que nada tem a perder com as greves" ${ }^{67}$ Através desta passagem percebe-se que, de uma forma paternalista, o governo se

\footnotetext{
${ }^{64}$ O Operário em face das Leis do Estado. A Federação. Porto Alegre: 1ㅇ/01/1922, p. 03.

${ }^{65}$ As Greves. A Federação. Porto Alegre: 03/03/1911, p. 02.

${ }^{66}$ As Greves. A Federação. Porto Alegre: 03/03/1911, p. 02.

67 O Fim da Greve. A Federação. Porto Alegre: 10/03/1911, p. 03.
} 
responsabilizava pela tarefa de livrar os trabalhadores de boa fé da tutela de elementos perigosos, tal qual um pai adverte o filho que julga andar em más companhias.

Mas se as greves eram criticadas pelo governo, de que maneira ele imaginava que os operários atingiriam o seu bem estar? Pensa que de duas maneiras: a primeira delas é relegar ao governo esta tarefa e a segunda é esperar que os efeitos naturais do progresso resultante da primazia da ordem trouxessem melhorias nas condições de vida dos trabalhadores. Quanto à alternativa da ação paternalista, o progresso social e a melhoria das condições de vida dos trabalhadores eram vistos como uma dádiva do governante que afirmava ser de sua doutrina "trabalhar para melhorar a sorte do proletariado, dar-lhe o conforto de que é digno como eficaz e decisivo colaborador do progredir humano"68. Apresentava-se com uma visão paternalista do mundo social na qual o Estado deveria prover os trabalhadores com o bem estar. As vantagens almejadas pelos trabalhadores não seriam, através desta visão, atingidas por meio de conquistas e mobilizações - desordem - e sim através de dádivas concedidas pelo Estado de modo que ao operário restaria esperar enquanto aquele trabalhava em seu benefício - ordem. Nesta perspectiva, o progresso social seria o resultado da manutenção da ordem.

A segunda forma de o operário atingir seu bem estar - e que complementa a primeira - seria aquela em que as soluções dos problemas sociais não poderiam ser forçadas por manifestações e greves descabidas e que a realização social do operariado ocorreria no processo da evolução humana. "A evolução humana fá-lo-á [ao operário] percorrer a sua trajetória e alcançá-la em todos os pontos da curva, queira ou não queira a vontade de meia dúzia de desorientados" ${ }^{69}$ Esta visão tem como pressuposto o fato de que a evolução natural da sociedade através da manutenção da ordem levaria inevitavelmente a um período de realizações no qual as necessidades de todos seriam satisfeitas.

Tendo em vista o fato de que as atitudes grevistas eram tradicionalmente condenadas pelo governo e consideradas momentos de desordem - ou para continuar utilizando a metáfora anterior, um desacato perante a autoridade paternal - e que o Estado

\footnotetext{
${ }^{68}$ A Federação. Porto Alegre: 03/03/1911, p. 03.

69 A Federação. Porto Alegre: 03/03/1911, p. 03.
} 
utilizava com freqüência a força pública para reprimi-las ${ }^{70}$, pode-se inferir que o paternalismo foi uma estratégia de acomodação das possíveis perturbações sociais a fim de granjear a simpatia dos trabalhadores tanto no sentido de evitar agitações sociais quanto no sentido de mobilizar potenciais eleitores.

O 'paternalismo borgista' que visava a 'incorporação do proletariado à sociedade' baseado nos princípios de Comte foi uma política utilizada somente "até o momento em que a ideologia, como justificativa, não atendeu mais aos interesses do Estado na solução da questão social” ${ }^{\prime 11}$, ou seja, quando a ação paternalista mostrava-se incapaz de evitar que eclodissem os conflitos de classe ou então de contorná-los, esta passava a dividir espaço com a ação repressora, com a utilização do aparato policial contra os operários, sendo que, muitas vezes, esta repressão tinha uma justificativa que evocava elementos do paternalismo para se legitimar. Esta justificativa consistia em afirmar que o Estado estava, através da utilização do aparato policial, protegendo os trabalhadores da "tutela revolucionária e anarquizadora" à qual os mesmos estariam sendo submetidos.

Se, como bem demonstra Silva Jr. ao analisar a greve geral de $1917^{72}$, a questão do paternalismo deve ser relativizada visto que "nem as lideranças da greve, nem o conjunto dos grevistas assumiram quaisquer compromissos paternalistas" arriba) un acto de conceción, es (desde abajo) un acto de lograr"74, deve-se levar em consideração que o restante da sociedade e, principalmente, os trabalhadores que não

\footnotetext{
70 Exceção feita à greve de 1917 quando Borges de Medeiros reconheceu a legitimidade das reivindicações dos operários conferindo um impulso à mesma. Ver: SILVA Jr, Adhemar Lourenço. "Povo! Trabalhadores!": tumultos e movimento operário. Dissertação de mestrado. UFRGS, 1994.

71 PESAVENTO, Sandra J. 'República Velha Gaúcha: Estado Autoritário e Economia'. In: DACANAL, J.H. e GONZAGA, Sérgius (org.). RS: Economia e Política. Porto Alegre: Mercado Aberto, 1979, p. 227.

72 Apesar de estar me referindo neste momento à greve de 1917, não pretendo aqui analisá-la mais detidamente. No entanto, a questão que se insere neste momento é a que está relacionada à atitude de Borges de Medeiros de baixar dois decretos e um ato administrativo nos quais ele limita a exportação de gêneros alimentício, buscando reduzir deste modo a carestia que se generalizava no estado, aumentando os salários dos funcionários a serviço do estado e criando feiras populares. A greve de 1917 ocorreu no bojo de uma série de agitações sociais que se espalharam por várias cidades brasileiras tendo como contexto imediato a eclosão da primeira guerra mundial e seus inevitáveis reflexos que resultaram em uma progressiva carestia agravada pela exportação de gêneros alimentícios para os países envolvidos no conflito. Sobre esta greve ver: PETERSEN, Sílvia Regina. As Greves no Rio Grande do Sul. In: DACANAL, J.H. (org.). RS: Economia e Política. Porto Alegre: Mercado Aberto, 1979.; SILVA Jr., Adhemar Lourenço da. A Greve Geral de 1917 em Porto Alegre. Anos 90. Porto Alegre: UFRGS, 1996, n. 5; BODEA, Miguel. A Greve de 17 e as Origens do Trabalhismo Gaúcho. Porto Alegre: Pro-Arte/L\&PM, s.d.; KLIEMANN, Luíza. 1917: Convergência de Interesses, Governo Autoritário e Movimentos Operários. Estudos Ibero-Americanos. Porto Alegre: PUC-RS, 1980, n. 2.

73 SILVA Jr, Adhemar Lourenço da. Op. Cit. 1996, p. 195.

74 THOMPSON, E. P. Apud: SILVA Jr, Adhemar Lourenço da. Op. Cit. 1996, p. 195.
} 
estavam diretamente envolvidos na greve se deparavam com duas interpretações sobre as medidas tomadas por Borges de Medeiros ao fim da greve de 1917: se por um lado o governo buscava passar a imagem de que estava protegendo os operários, fazendo concessões que viriam beneficiar o conjunto dos trabalhadores, por outro lado as lideranças operárias entendiam que as eventuais "concessões" feitas pelo Estado eram de fato conquistas dos trabalhadores que se mobilizaram e conseguiram arrancar do governo alguns benefícios.

Com relação aos próprios operários, sobretudo os que não se envolveram na greve, é possível relativizar a interpretação de que estes não entendiam as concessões feitas pelo governo na ocasião da greve de 1917 como "compromissos paternalistas" ${ }^{75} \mathrm{Se}$, por um lado, observa-se os discursos dos líderes operários, afirmando que "o começo da vitória estava sendo alcançado"76 e buscando considerar as medidas do governo como conquistas do operariado e não como concessões feitas paternalisticamente, por outro, estes discursos podem representar estratégias de convencimento dos líderes operários para impor/propor aos trabalhadores e à sociedade a sua própria visão de mundo. Assim pode-se inferir que o discurso do governo do estado, privilegiando uma atuação de caráter paternalista, pode ter tido alguma penetração entre os trabalhadores menos politizados, representando outra leitura para o término do episódio.

Seria difícil saber realmente de que modo os trabalhadores menos atuantes no movimento operário e mesmo aqueles que não se envolviam nas greves percebiam esta relação, visto que estes trabalhadores dificilmente deixaram algum registro que possibilite esta análise e que "apenas uma minoria chega a escrever nos jornais operários e tem uma atuação que transcende os limites de sua categoria profissional". ${ }^{77}$ É difícil para o historiador saber de fato o que pensava a grande massa de trabalhadores que não participava da organização das greves ou mesmo que não aderia a elas uma vez que "as maiorias sem linguagem articulada, por definição, deixam pouco registro de seus pensamentos". ${ }^{78}$

\footnotetext{
${ }^{75}$ SILVA Jr. Adhemar. Op. Cit. $1996 . \quad$ p. 195.

76 SILVA Jr, Adhemar L. da. Op. Cit. 1996. p. 195.

77 BATALHA, Cláudio. Op. Cit. p. 93.

78 THOMPSON, E. P. A Formação da Classe Operária Inglesa. Rio de Janeiro: Paz \& Terra, 1987, vol. I, p. 57.
} 
Assim, mesmo que se entenda que as lideranças operárias não estivessem dispostas a considerar as atitudes do governo do estado como "concessões", deve-se levar em consideração que a própria questão do paternalismo transforma-se em um elemento de disputa entre os trabalhadores e o Estado na medida em que ambos possuem diferentes visões do mundo social, construídas a partir da "posição ocupada no espaço social"79 de modo que pode-se entender o paternalismo como um mecanismo ideológico resultado da posição em que o Estado se encontra no espaço social, como representante da classe dominante, configurando-se em mais uma área de disputa entre o Estado e os operários.

\section{O discurso de harmonia social}

O terceiro ponto a ser destacado está relacionado à forma como o governo percebia a configuração das relações sociais no estado e à maneira com que pretendia impor/propor esta visão ao restante da sociedade. Através de um discurso perpassado por uma "leitura harmônica do social" ${ }^{80}$ na qual o Estado seria o agente emulador do progresso irrefreável e que este ocorreria indiscriminadamente e sem sobressaltos, buscava-se transmitir ao conjunto da sociedade a idéia de que "sem perturbações nem retrocessos desdobra-se a evolução social sob as inspirações da fecunda continuidade política e administrativa". ${ }^{81}$ Assim, o governo do estado atendia aos interesses de todas as classes indistintamente, sendo ele o impulsionador do desenvolvimento harmônico do estado por contar com "o apoio estimulante de todas as classes sociais". ${ }^{2}$

Do mesmo modo, entendia-se que o grau de desenvolvimento das potencialidades econômicas fazia com que aqui não tivessem se estabelecido os "vícios" que lá provocavam tantas turbulências no âmbito social. Protásio Alves, secretário do estado dos Negócios do Interior e do Exterior, afirmava que "a falta de motivos para as greves entre nós, onde a vida do operário não é rude como na Europa, deram-lhe pouca duração". ${ }^{83}$ Além desta diferença

\footnotetext{
79 BOURDIEU, Pierre. Op. Cit. 1997, p. 27.

80 PESAVENTO, Sandra J. Trabalhadores e Máquinas: Representações do Progresso. Anos 90. Porto Alegre: 1994, n. 2, p. 180.

81 Mensagem do Presidente do Estado à Assembléia dos Representantes. 1907. Faço aqui a ressalva de que nas mensagens em que não referencio a página da citação é porque as mesmas não se encontram numeradas.

82 Mensagem do Presidente do Estado à Assembléia dos Representantes. 1903.

83 Relatório apresentado ao Ex.mo Sr. Dr. Antônio Augusto Borges de Medeiros Presidente do Estado - pelo Dr. Protásio Alves Secretário do Estado dos Negócios do Interior e do Exterior - em 30 de agosto de 1920.
} 
nos níveis de desenvolvimento existia outra substancial diferença que colaborava para que aqui os problemas sociais não se acentuassem, uma vez que no estado "o governo e a legislação atuam, em harmonia com os demais fatores do desenvolvimento social, para estimular a tendência positiva ao estabelecimento do regime pacífico-industrial, único capaz, consequentemente, de concretizar as aspirações da fraternidade humana, conforme as iniludíveis indicações do passado moderno". ${ }^{44}$ Nesta passagem, Borges salienta que o governo atua em harmonia com os vários segmentos da sociedade e que por isto não haveria motivos para revoltas por parte do operariado. Esta idéia permanece no discurso do PRR, tanto que em 1920, em artigo d'A Federação, ela é novamente retomada quando se salienta que "o hábito de legislar para o povo, outorgando-lhe a plena garantia dos seus direitos [...] evitou que a conquista das aspirações operárias pudesse assumir a forma violenta e anárquica por que essas aspirações, agora, destroem o princípio da ordem do velho mundo e fazem vacilar toda uma civilização, trabalhada em longos e penosos séculos de lutas memoráveis". ${ }^{85}$ Este discurso de harmonia social, apesar de permanente no período estudado, não encontra respaldo nas condições sociais objetivas que eram permeadas por uma constante luta de classes.

\section{A repressão como forma de solução para os conflitos sociais}

A despeito do discurso do PRR, que é constantemente pautado pela afirmação de que o Estado trabalha continuamente para a solução da questão social e que busca difundir um sentimento de harmonia social, as práticas do governo são perceptivelmente contraditórias. As agitações sociais e as manifestações dos trabalhadores habitualmente foram alvo da ação repressora da força pública ocorrendo inclusive a morte de operários.

Apesar da postura assumida por Borges de Medeiros durante a greve de 1917, na qual ele em parte atendeu as exigências dos operários, promovendo o diálogo e procurando, através da concessão de aumentos de salários para os funcionários a serviço do Estado, dar o exemplo para a relação entre os patrões e seus operários, percebe-se que as greves ao longo do período foram merecedoras da condenação do governo. A greve geral de 1918 em

\footnotetext{
84 MEDEIROS, Borges de. Discurso Pronunciado a 19 de maio de 1916, p. 5-6.

${ }^{85}$ Os Operários em Face das Leis do Estado. A Federação. Porto Alegre: 1ㅇ/01/1920.
} 
Porto Alegre ${ }^{86}$ é um exemplo ilustrativo disto, principalmente porque Borges de Medeiros foi, pessoalmente, junto com a Brigada Militar, providenciar para que a Cia Força e Luz, em greve, recomeçasse os trabalhos. A Brigada foi mobilizada para evitar a greve, o que se justificava pelo fato de, como dizia a imprensa, "a greve atual não [ter] pé nem cabeça, não podendo a classe operária lançar a perturbação na ordem social indispensável à tranqüilidade pública, ao livre exercício do trabalho produtivo que cumpre acautelar e proteger" ${ }^{87}$ Percebe-se que apesar de o direito de greve estar assegurado na constituição estadual e constar no item J do programa político do PRR, o Estado se vê no direito de intervir toda a vez que considerar que esta ameaça a ordem social. Assim, durante a greve de 1918 o governo manifestou-se contra a parede, afirmando que "o Governo do Estado acha-se no firme propósito de reprimir este movimento, que não tem objetivos plausíveis e somente poderia acarretar prejuízos no momento difícil que atravessamos". ${ }^{88}$

A ação repressora da polícia durante o movimento era justificada pelo fato de que "o governo tem o dever de proteger nosso operariado contra a influência maléfica desse proselitismo revolucionário". ${ }^{89}$ Percebe-se que novamente o Estado se apresentava de forma paternalista, tentando fazer com que o operariado aparecesse como vítima de uma orientação maléfica de elementos anarquistas perniciosos, e não como vítima da exploração de seus patrões. Da mesma forma, as leis vigentes no Estado que dão algum benefício aos trabalhadores - como a que equipara as vantagens dos operários a serviço do Estado com as dos jornaleiros e diaristas - são alardeadas pelo governo como sendo uma prova de generosidade representando a "afirmação de um impulso generoso e mostra, à evidência, o liberalismo da lei suprema do Estado". ${ }^{90}$

Seguidamente percebem-se as queixas dos operários contra a ação repressora do governo, que não raras vezes utilizou-se da força pública para evitar que tais greves lograssem êxito. Durante a greve geral de 1919, os operários denunciavam que "os inomináveis exploradores obrigam a sair os bondes guardados por soldados. [...] com manifesta provocação aos grevistas ultrapacíficos" e que os bondes saíam com "homens

\footnotetext{
${ }^{86}$ Sobre a greve geral de 1918 em Porto Alegre ver: QUEIRÓS, César Augusto. O Positivismo e a Questão Social na Primeira República. Guarapari: Ex Libris, 2006. PETERSEN, Sílvia. Que a União Operária seja nossa Pátria. Porto alegre: UFRGS, 2005.

87 A Greve - Providências do Governo. A Federação. Porto Alegre: 22/07/1918, p. 03.

88 A Greve - Providências do Governo. A Federação. Porto Alegre: 22/07/1918, p. 03.

89 Anarquistas e Derrotistas. A Federação. Porto Alegre: 29/07/1918, p. 05.

90 O Operário em face das Leis do Estado. A Federação. Porto Alegre: 10/01/1922, p. 03.
} 
forçados entre baionetas". ${ }^{91}$ Os operários percebiam a cumplicidade entre o governo e a burguesia gaúcha e denunciavam "as forças do governo postas ao serviço da burguesia". ${ }^{92}$ As manifestações e greves dos trabalhadores eram recebidas pelo governo como sendo "manifestação sediciosa que merece ser reprimida com as armas e as balas compradas com o dinheiro do povo para a defesa da pátria dos senhores". ${ }^{93}$

É irônico observar que o governo sustentava o privatismo e a não intervenção do Estado nas relações entre capital e trabalho justamente em um momento em que acabara de acionar seus mecanismos repressores a fim de conter uma greve que se estava propagando na capital. Nesta ocasião, os operários de várias categorias, liderados pelos operários da Cia Força e Luz, declararam-se em greve (agosto de 1918) e a postura tomada por Borges de Medeiros foi a de pessoalmente conduzir a força pública até a Cia Força e Luz para obrigar os operários a continuarem trabalhando. Segundo o jornal operário $O$ Syndicalista - que era o órgão de representação da Federação Operária do Rio Grande do Sul - “em 1918, quando houve uma tentativa de greve geral, tendo os operários da usina da Força e Luz abandonado o trabalho, o governo violou os seus lares, arrancando-os de casa a baioneta, obrigando-os a trabalhar no fogo contra a vontade, fazendo-os dormir ali, etc." ${ }^{\prime 94}$

No que se refere ao conflito de interesses entre patrões e empregados, o PRR mantinha uma posição ambígua entre o discurso e a prática, visto que se por um lado o governo defendia o entendimento direto entre os patrões e os empregados e a intervenção do Estado como mediador somente em casos de difícil resolução, defendendo, assim, o privatismo nas relações de produção, por outro, toda a vez que este conflito assumia proporções mais amplas o governo tomava medidas coercitivas com a utilização do aparato policial para a repressão dos movimentos grevistas.

Tendo em vista que o positivismo fornece uma série de elementos que permeiam tanto o discurso quanto a atuação do PRR, é interessante recorrer novamente à ideologia a fim de analisar melhor a relação entre repressão e questão social. Os princípios positivistas são invocados com freqüência no que concerne à questão social, de modo que Borges de

\footnotetext{
91 A Voz da Razão. Manifesto da FORGS dirigido ao povo. Porto Alegre: 7/09/1919.

92 Syndicato dos Operários da Força e Luz. Porto Alegre: 1919. Anexo ao processo-crime n.o 1016.

${ }_{93}$ Aos Pedreiros e Ajudantes. Porto Alegre: 1919. Anexo do processo-crime n.o: 1.016.

${ }^{94}$ O Syndicalista. Porto Alegre: 03/09/1919, n. 7, p. 1.
} 
Medeiros, na ocasião da greve de 1917, afirmou desejar, "à luz dos ensinamentos de A. Comte, promover definitivamente a incorporação do proletariado na sociedade moderna" ${ }^{95}$

Apesar da incorporação do proletariado à sociedade moderna ser um princípio caro aos positivistas a forma como se daria esta incorporação não era colocada de uma forma suficientemente clara. Assim, vê-se que para o estabelecimento de uma 'sociedade científica', os trabalhadores deviam ser preparados para "respeitarem e mesmo reforçarem as leis naturais da concentração do poder e da riqueza". ${ }^{96}$ Aliás, a desigualdade social e a distribuição desigual do produto do trabalho são, de acordo com a doutrina positivista, subordinadas a "leis naturais, que no sistema de sociabilidade moderno, devem determinar a indispensável concentração das riquezas entre os chefes industriais". ${ }^{97}$ Comte afirmava que agitações sociais e de operários poderiam irromper em um período transitório, no qual a 'disciplina industrial' positivista ainda não tivesse se espalhado por toda a sociedade. No entanto, estes fenômenos deveriam ser enfrentados com uma "ativa participação dos exércitos propriamente ditos na sustentação permanente da ordem pública". ${ }^{98}$

Esta ativa participação "dos exércitos", mesmo que não estivesse presente no discurso do PRR, pode ser verificada na prática em várias ocasiões, como na greve de 1919 tanto em Rio Grande quanto em Porto Alegre. Durante esta greve, a Brigada Militar foi fortemente utilizada, sendo que Borges de Medeiros afirmara que "durante a greve que estalou nesta capital em agosto do ano findo, teve ocasião a Brigada Militar de se tornar mais uma vez, credora do reconhecimento da população de Porto Alegre, pelo modo enérgico e eficaz como se conduziu naqueles dias em que o desvario criminoso de elementos anarquistas, explorando a boa fé do verdadeiro operariado, perturbou em várias ocasiões a ordem pública com injustificados atentados individuais e à propriedade". 99 Esta afirmação, enaltecendo a ação enérgica da Brigada Militar contra os elementos grevistas, demonstra claramente que a questão social era tratada como um momento de desordem pública o qual deveria ser reprimido através da utilização do aparato policial. Assim, fica clara a forma pela qual o proletariado deveria ser incorporado à sociedade, aprendendo a respeitar as leis

\footnotetext{
95 Mensagem do presidente do Estado à Assembléia dos Representantes. 1918.

96 COMTE, Augusto. Apud LOWY, Michael. As Aventuras de Karl Marx contra o Barão de Münchhausen. 5aed, São Paulo: Cortez, 1994, p. 24.

97 COMTE, Augusto. Op. Cit., p. 24.

98 COMTE, Augusto. Ibidem, p. 59.

99 Mensagem do Presidente do Estado à Assembléia dos Representantes. 1920.
} 
naturais de concentração de riquezas. Para o governo, as greves eram orientadas por "grevicultores" 100 , elementos "que procuram levedar e implantar no proletariado nacional a sua ação subversiva e perigosa. Tratam-se de anarquistas estrangeiros professos e confessos". 101

Neste artigo procurou-se, em um primeiro momento, analisar algumas características gerais do Partido Republicano Rio-Grandense, ressaltando pontos ligados às suas diretrizes ideológicas compromissadas com o positivismo de Augusto Comte. Dentre estes, destacou-se a concentração de poderes nas mãos do Executivo - prática inspirada no conceito de ditadura positivista -, a continuidade político administrativa adaptada à realidade republicana, a exclusão das classes subalternas e a incorporação do proletariado à sociedade moderna como pontos importantes do discurso do PRR, atentando também para a composição social do partido - que passara a incorporar novos segmentos da sociedade visto que não contava com o apoio das elites tradicionais - e para o processo de renovação das lideranças, corporificado na transmissão do cargo de Presidente do Estado de Júlio de Castilhos para Borges de Medeiros até a morte de Castilhos, quando Borges acumulou a Presidência do Estado e a do partido, mantendo os mesmos ideais e princípios adotados por Castilhos.

Em um segundo momento, procurou-se analisar propriamente a relação entre o PRR e a questão social, ou seja, entre o Partido Republicano Rio-Grandense de posse do governo do Estado do Rio Grande do Sul e os trabalhadores gaúchos organizados em movimento operário para reivindicar o bem estar para a classe. Assim, percebeu-se que apesar do PRR advogar um discurso que privilegiava a harmonia entre as classes sociais no Rio Grande do Sul, destacando o esforço paternalista feito pelo Estado para defender os interesses dos trabalhadores e afirmando que os conflitos entre patrões e empregados deveriam ser resolvidos no âmbito privado através da negociação entre as partes interessadas, cabendo ao Estado somente o papel de mediador destas negociações, na prática, o tratamento aos trabalhadores era outro, pautado pela constante utilização da força pública na repressão de greves e manifestações operárias, a despeito de o direito de greve estar garantido na Constituição do Estado. A Brigada Militar foi constantemente

100 O Fim de Greve. A Federação. Porto Alegre: 10/03/1911. p. 01.
101 Os Anarquistas e a Ação do Governo. A Federação. Porto Alegre: 26/03/1917. p.03. 
acionada no sentido de reprimir a manifestação dos operários, de manter a ordem pública ou de garantir que os serviços não fossem paralisados - como nos casos das greves de bondes e da Cia Força e Luz.

Deste modo, percebeu-se um comportamento contraditório e ambíguo nas relações do PRR com o movimento operário, caracterizado por um discurso que sustentava o privatismo nas relações entre capital e trabalho quando, na realidade, o Estado intervinha constantemente em socorro de uma das partes envolvidas através da utilização de seu corpo policial; mostrava-se defensor dos interesses da classe operária, através de um discurso paternalista, mas, com raras exceções, posicionava-se no lado oposto toda a vez que a luta de classes tornava-se mais perceptível; enfim, a postura do PRR em relação à questão social era composta por um discurso e uma prática contraditórios, chegando a ser, em termos objetivos, praticamente incompatíveis dada a distância existente entre um e outro. 